\title{
Thermal Performance Study on a Sensible Cool Thermal Energy Storage System for Building Air-Conditioning Applications
}

\author{
Kesavan Muthaiyan $\left(D,{ }^{1}\right.$ Chidambaram Lakshmanan, ${ }^{1}$ Kaiwalya Raj, ${ }^{2}$ Mangat Ram Sharma, ${ }^{2}$ \\ Rajamani Narayanasamy $\mathbb{D}^{2},{ }^{2}$ Pandiyarajan Vellaichamy $\mathbb{D D}^{3}$ and Velraj Ramalingam $\mathbb{D}^{2}$ \\ ${ }^{1}$ Mechanical Engineering, Annamalai University, Annamalainagar, 608002, India \\ ${ }^{2}$ Institute for Energy Studies, CEG, Anna University, Chennai 600 025, India \\ ${ }^{3}$ Department of Chemical Engineering, Anna University, Chennai 600 025, India
}

Correspondence should be addressed to Kesavan Muthaiyan; kesavanapme@gmail.com

Received 11 December 2020; Revised 29 January 2021; Accepted 26 May 2021; Published 8 June 2021

Academic Editor: Kumarasamy Sudhakar

Copyright (c) 2021 Kesavan Muthaiyan et al. This is an open access article distributed under the Creative Commons Attribution License, which permits unrestricted use, distribution, and reproduction in any medium, provided the original work is properly cited.

\begin{abstract}
In most developed and developing nations, nearly $40 \%$ of the energy generated is utilized in the building sector, in which nearly $50 \%$ of the energy is consumed by building cooling/heating systems. However, the energy requirement for building cooling/heating varies continuously with respect to time. Hence, in hot countries, if the cooling system is integrated with a storage system, the cooling system need not be designed for the peak load requirement. Further, this kind of storage system is very useful and economically beneficial in the scenario of dynamic electricity tariff, being introduced in many countries in the emerging renewable energy scenario to solve the grid stability issues. Further, it is very useful to promote microgrid with distributed renewable power generation. Considering the above, the major objective of the present research is to demonstrate the integration of the air-conditioning system with a sensible heat storage unit for residential applications. An experimental setup is constructed, and experiments were conducted to evaluate the heat exchange behavior during the charging and discharging process by varying the inlet temperature and the mass flow rate of the heat exchange fluid through the circuit. It is observed that the set temperature of the cool storage tank is to be maintained above $+5^{\circ} \mathrm{C}$ to achieve better efficiency during the charging process. During the discharging process, the room could be maintained at the required comfort condition for a duration of 285 min with 29 cycles of operations between the set point temperature limits of $25^{\circ} \mathrm{C}$ to $28^{\circ} \mathrm{C}$. When the inlet brine temperature of the cooling unit reached $20^{\circ} \mathrm{C}$, in the next cycle, bringing down the room temperature again to $25^{\circ} \mathrm{C}$ could not be achieved. The results shown in this work are beneficial for efficiently operating the cooling system and useful in promoting renewable energy in the near future in the building sector. Also, the low-temperature sensible heat storage system is capable of maintaining the storage temperature at approximately $+4^{\circ} \mathrm{C}$, instead of $-4^{\circ} \mathrm{C}$ normally employed in the case of latent heat-based storage system that allows higher performance in the sensible heat storage system.
\end{abstract}

\section{Introduction}

The development of a nation mostly depends on the production of power, effective utilization of energy, and environmental condition. In most developed and developing nations, the energy consumption by the building sector is nearly $40 \%$ of the total energy produced [1]. In hot climatic countries like India, the major share of energy is utilized in buildings by large capacity AC units that consume approximately $50 \%$ of the energy spent on building [2]. Hence, these countries near the equator spend nearly $20 \%$ (50\% of $40 \%$ ) of the total power generated for air-conditioning. Hence, scientists are targeting the energy-intensive air-conditioning sector, for energy efficiency, building demand-side management, and the introduction of renewable energy. In the recent years, there are different control strategies established in the air-conditioning for energy-efficient operation of the chiller system. Further, the load requirement in the central airconditioning system is very high during the afternoon hours, particularly in the commercial buildings. Accordingly, the 
chiller systems are designed to meet the peak load demand, and hence, the capacity of the chiller is usually more than twice the average load requirement. Considering the above, the cool thermal storage systems are introduced in some of the building air-conditioning systems between the chiller and the air-handling units, thereby the chiller capacity requirement could be reduced to $50 \%$ of the peak load requirement. The various research work available in the literature about this kind of storage system in the present energy scenario is detailed in this section.

Sebzali et al. [3] demonstrated the employment of the chilled water energy storage (CWES) system, which for any design day condition, reduced the peak electricity demand and annual energy consumption for AC systems in the range of $36.7 \%-87.5 \%$ and $4.5 \%-6.9 \%$, respectively, compared with conventional cooling systems, where pumps and chillers extensively contributed to reduction in energy consumption. They showed that a load-leveling strategy applied to the CWES system resulted in the lowest life cycle cost (LCC) compared to full storage and 50\% demand limiting strategies and was the most cost-effective choice for both the electric utilities and the consumers. Lin et al. [4] studied the impact of energy-saving by incorporating LTSHS along with the air-conditioning system. Two systems were studied: one system used chilled storage technology, and the other system utilized some parts of chilled water back from the user. They concluded that both systems could save energy and power cost compared with traditional chilled storage systems. Velraj et al. [5] studied the integration of the cool thermal energy storage (CTES) system, along with a large building AC system. The authors mentioned various advantages of the coupled system and also demonstrated a saving of INR 2.26 million per annum with the storage integrated system for the building considered in their work.

Kim et al. [6] examined the thermal performance of the thermal energy storage (TES) integrated outdoor air system used in a daycare center located in Jincheon. The results indicated an increase in total cooling load by $48 \%$ and a saving of up to $38 \%$ in the energy consumption than existing systems. Yan et al. [7] described an optimization method for the combined cool storage (CCS) system where the cool energy for the building cooling in summer was provided by the CWES system, which utilized the cool energy from the heat pipebased seasonal ice storage wherein the low ambient temperature was used to freeze the ice. The optimization methodology was also implemented in a real building situated in Beijing. Their results showed that compared to the conventional cooling system, the proposed CCS system in the building could reduce the operational cost, annual electricity consumption, and life-cycle cost by $76 \%, 22 \%$, and $40 \%$, respectively.

Boonnasa and Namprakai [8] reported an approach to find the optimal chilled water energy storage (CWES) capacity and operating strategies for the AC loads at various electricity tariffs. They concluded that the continuous operation of the CWES system comprising two chiller units of cooling capacity 450 TR each, a cool storage of 9413 ton-hr, and volume of $5175 \mathrm{~m}^{3}$ was found to be suitable. Further, $35.7 \%$ of energy consumption was shifted from the on-peak to the off-peak periods. They also concluded that the nighttime operation of the mechanical chiller could increase the COP of the cooling chiller. Sebzali and Rubini [9] studied the effect of integrating the CWES system with air-cooled chillers and its impact on the energy performance for the Kuwaiti climate. They showed that the results for the peak design day, chillers operating with demand limiting, and load-leveling partial storage strategies resulted in $4 \%$ higher energy consumption than a conventional system. The full storage strategy resulted in a $4 \%$ lower energy consumption compared to the conventional system. Therefore, it was concluded that the full storage strategy operated CWES system was the optimal choice for the Kuwaiti climate.

Song et al. [10] studied the economic viability of the implementation of ice storage and chilled water storage combined LTSHS system for building cooling applications. They concluded that the addition of an ice thermal storage system into an existing CWES system significantly reduced the design day operating cost. Lin et al. [11] presented a methodology to evaluate the thermoeconomic performance of a CWES system in which the return cool water (i.e., from the load side) was mixed with the supplied chilled water (i.e., from the chiller side). Operation cost and exergy consumption were cut down by $15 \%$ for the above system compared with the CWES system, which directly utilized chilled water at $5^{\circ} \mathrm{C}$. Henze et al. [12] developed a program to optimize the chiller operation and the storing/extracting (i.e., cool energy) strategies of the CWES system. Due to more cooling demand in a pharmaceutical building that already had ten chillers installed, an investigation was done to find the viable option between adding an extra chiller and integrating the CWES system. The program developed was also utilized to find the economic and operational benefits of installing a CWES system over the addition of an extra chiller. It was concluded that the integration of a CWES system was expected to provide energy cost savings. The incorporation of the CWES system in the existing cooling system improved the availability and the reliability.

Rosiek and Garrido [13] studied the performance of a solar-thermal operated vapour absorption chiller system with chilled water storage tanks for building cooling application. It was noticed that the efficiency of the solar-assisted cooling system got improved owing to the reduction in chiller on/off cycles due to the incorporation of chilled water storage tanks. Also, a maximum saving in water resource consumption, total electrical energy consumption, and $\mathrm{CO}_{2}$ emission was found to be about $30 \%, 20 \%$, and 1.7 tons, respectively, for the summer. Rosiek and Batlles [14] demonstrated a new operation strategy in monitoring real-time occupancy for a solar-assisted VARS-based air-conditioning system incorporated with chilled-water storage tanks to improve the system efficiency. It was found that the reduction in $\mathrm{CO}_{2}$ emission and total electrical energy usage was nearly 1.3 tons and $42 \%$, respectively. Mohammadi et al. [15] had introduced a methodology of enhancement for the day ahead planning of a multichiller framework consolidated with chilled-water storage. The modeling is done in GAMS software, and CONOPT was used as a solver. Four units of 2900 ton capacity multichiller system were used for simulation. The results 
show that the storage unit increased the robustness of the total cost against the variation in the cooling load. It was concluded that the storage unit was more efficient for the unit having a high cooling load during peak hours.

Alva et al. [16] reviewed different aspects of the thermal energy storage, which are as follows: (1) broad scope of storage field; (2) material for storage with their cost, physical properties, operational performance, and suitability for different applications; and (3) different kinds of TES systems. Different active TES systems were analyzed, such as packed bed, moving bed, thermocline, and fluidized bed, and various passive TES systems were also analyzed with their implementation in buildings, automobiles, textiles, etc. Design parameters, cost models, and operational issues of TES systems were also discussed. She et al. [17] reviewed various cooling techniques. The importance of cold storage is explained in terms of storing the cool energy at night (i.e., off-peak period) and utilizing the cool energy stored at day time (i.e., on-peak period). Based on types of cold storage utilization, it was classified into ice storage, chilled water storage, and phase change material-based cool energy storage. Li [18] has done a detailed review of the available technologies for sensible heat storage under various operating conditions and storage tank geometries in the aspects of sensible storage material, water stratification phenomenon, heat storage, heat transfer modes, and various influencing factors. The energy and exergy performance were investigated and summarized from the fluid mass flow rate, storage tank geometrical structure, fluid properties, fluid inlet temperature, etc. Li and Zheng [19] have explained and summarized performance enhancement of the various TES systems, including sensible, latent, and sorption. They systematically introduced various integration forms of TES for different applications, such as hot water supply, air conditioners, and heat pumps, with building construction systems and with power production cycles, cogeneration, food transport, solar cookers, and vehicle systems for thermal comfort. Rajamani et al. [20] have performed an experimental investigation on a packed bed cool storage system integrated with a chiller system which has major advantages in the central air-conditioning system for demand management strategies. They have initially performed an experiment for evaluating the subcooling behavior of the PCM with various pseudomonas concentrations. Further, they have performed experiments to determine the heat transfer behavior during the charging process in a cool thermal storage tank of capacity 50,000 kJ. They have presented the essential parameters such as reduction in subcooling, instantaneous and cumulative heat transfer during the charging process for the efficient operation.

It is observed from the literature that the cool thermal storage systems are normally employed for the demandside management in large building air-conditioning systems. There are no studies reported towards the supply sidemanagement like the integration of solar energy with the chiller operation. Further, it is not seen from the literature about the feasibility of integrating cool thermal energy storage in residential air-conditioning applications. Hence, the objective of the present study is to introduce a small capacity low temperature sensible cool thermal energy storage system with a residential cooling unit which could be integrated with a solar power generation unit. Further, the main problem associated with cool water storage tank is the limitation in bringing down the temperature below $0^{\circ} \mathrm{C}$ due to freezing which demands increased size of the storage tank. Considering the above, the present work is also focused on mixing an appropriate percentage of monoethylene glycol with water to develop a sensible cool thermal energy storage system to bring down the storage temperature even below $0^{\circ} \mathrm{C}$ and to study the charging/discharging performance of a lowtemperature sensible heat storage (LTSHS) system for room air-conditioning applications.

\section{Experimental Investigation}

In the present work, an experimental unit is constructed to charge the cool energy produced by a chiller in the LTSHS tank and discharge the cool brine in the LTSHS tank through a cooling coil unit kept inside the room for space cooling. An experimental investigation is done to study the feasibility of using an LTSHS tank integrated with a chiller system for residential space cooling applications. The experimental setup details and the charging/discharging experiments are presented in this section.

2.1. Experimental Setup. The experimental setup consists of a VCR system, LTSHS tank, a room, and a cooling coil unit as the major components, and the line diagram for the experimental unit is shown in Figure 1. The photographic view of the experimental unit is shown in Figure 2. The vapour compression refrigeration (VCR) system of 1 TR capacity produced chilled brine at a required temperature of $-5^{\circ} \mathrm{C}$. The LTSHS tank made up of stainless steel with a capacity of $0.212 \mathrm{~m}^{3}$ was filled with brine solution prepared from a mixture of distilled water and monoethylene glycol in a ratio of 6 $: 4$, which acted as a HEF. The specific heat $\left(C_{P}\right)$, freezing temperature, density $(\rho)$, and thermal conductivity $(k)$ of the heat exchanging fluid were $3.69 \mathrm{kJkg}^{-1} \mathrm{~K}^{-1},-25^{\circ} \mathrm{C}, 995$ $\mathrm{kgm}^{-3}$, and $0.3 \mathrm{Wm}^{-1} \mathrm{~K}^{-1}$, respectively. The storage tank was connected to the buffer tank of the VCR system, and the chilled brine produced in the chiller was circulated through this storage tank while performing the charging experimentation.

The VCR system has a buffer tank of capacity $0.009 \mathrm{~m}^{3}$ filled with brine to accommodate the evaporator coil, heating coil of $2000 \mathrm{~W}$ capacity, and a stirrer. A proportionate differential temperature controller (PDTC) was used to maintain a desired constant temperature in the buffer tank. This enabled the supply of a constant temperature HEF from the buffer tank to the LTSHS tank. Valves were provided to control the flow rate of HEF in the charging/discharging circuits. The brine flow from the chiller to the LTSHS tank and from the LTSHS tank to the cooling coil unit was measured using rotometers with the measuring range of 0-1000 LPH and 0-3 LPM, respectively. The cooling coil unit was kept in a room of size $2 \mathrm{~m} \times 2.7 \mathrm{~m} \times$ $2.72 \mathrm{~m}$, and it was maintained at a controlled temperature of $25^{\circ} \mathrm{C}$ to $28^{\circ} \mathrm{C}$ during the discharging experiment. This cooling coil unit was connected to the LTSHS tank by a 


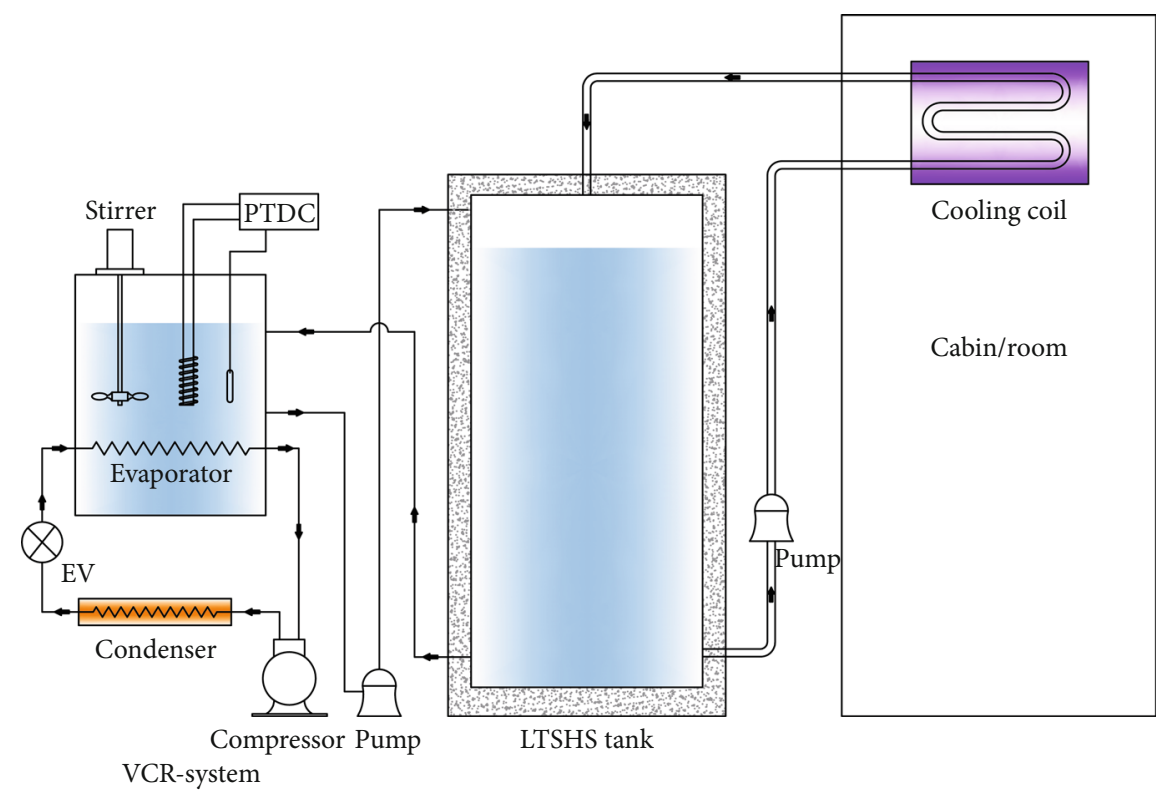

Figure 1: Schematic view of the experimental setup.

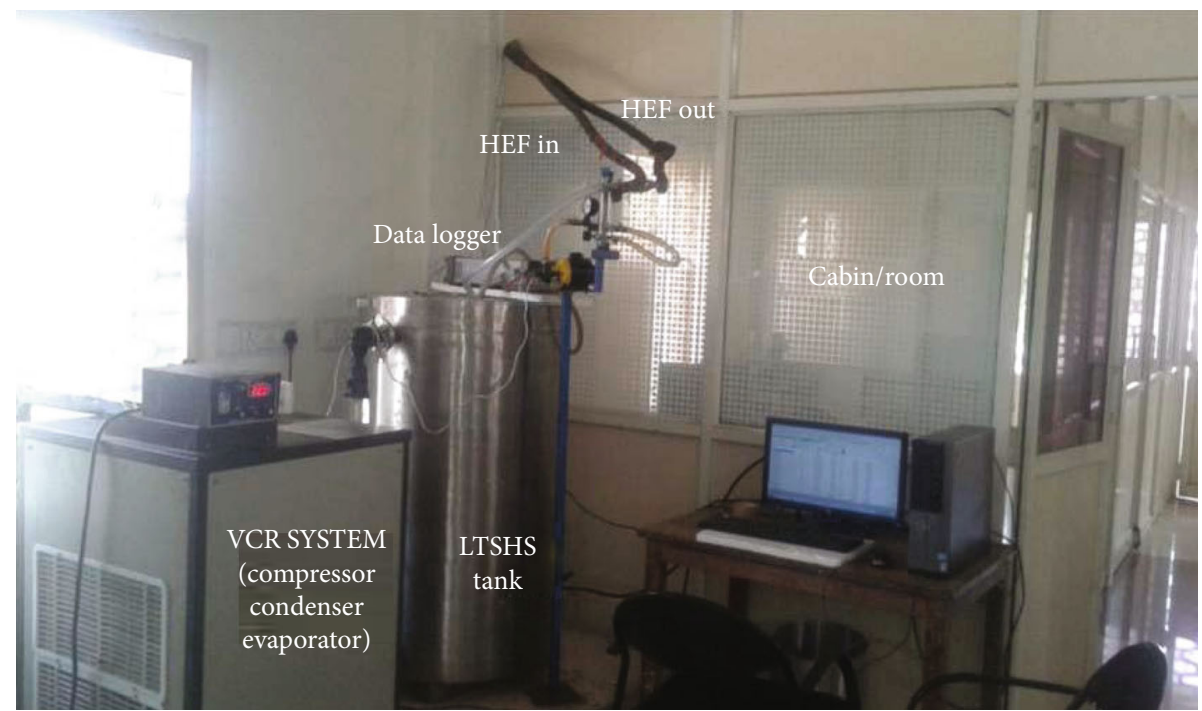

Figure 2: Photographic view of the experimental setup.

$6 \mathrm{~mm}$ diameter pipe, properly insulated with foam material. T-type thermocouples were utilized to measure the inlet, outlet, and inside temperatures of the LTSHS tank during the charging process. Two thermocouples of PT 100-RTD with an accuracy of $\pm 0.1^{\circ} \mathrm{C}$ were kept at inlet and outlet locations of the cooling coil unit for the brine temperature measurement. Further, 3 RTDs were kept at various locations in the room to measure the room air temperature during the discharging process. Agilent makes the 34972A data acquisition system with an accuracy of $0.004 \%$ to connect the temperature sensors. In both the charging and discharging circuits, $100 \mathrm{~W}$ capacity pumps were used for the circulation of the brine.
2.2. Experiments. The experiments were performed to study the charging and discharging performance of the developed system. During the charging experiment, brine was circulated from the buffer tank of the chiller unit to the LTSHS tank through a pump, and a flow rate of $400 \mathrm{LPH}$ was maintained by adjusting the valves. The chiller unit was operated at a constant load. HEF temperature of $-5^{\circ} \mathrm{C}$ was maintained in the buffer tank by the PDTC and for varying the heating coil output based on the temperature sensor located in the HEF bath of the buffer tank. The brine temperature was measured at an interval of 10 seconds during the entire experiment using a data logger and stored in the desktop PC connected to the experimental setup, and also, energy meter readings 


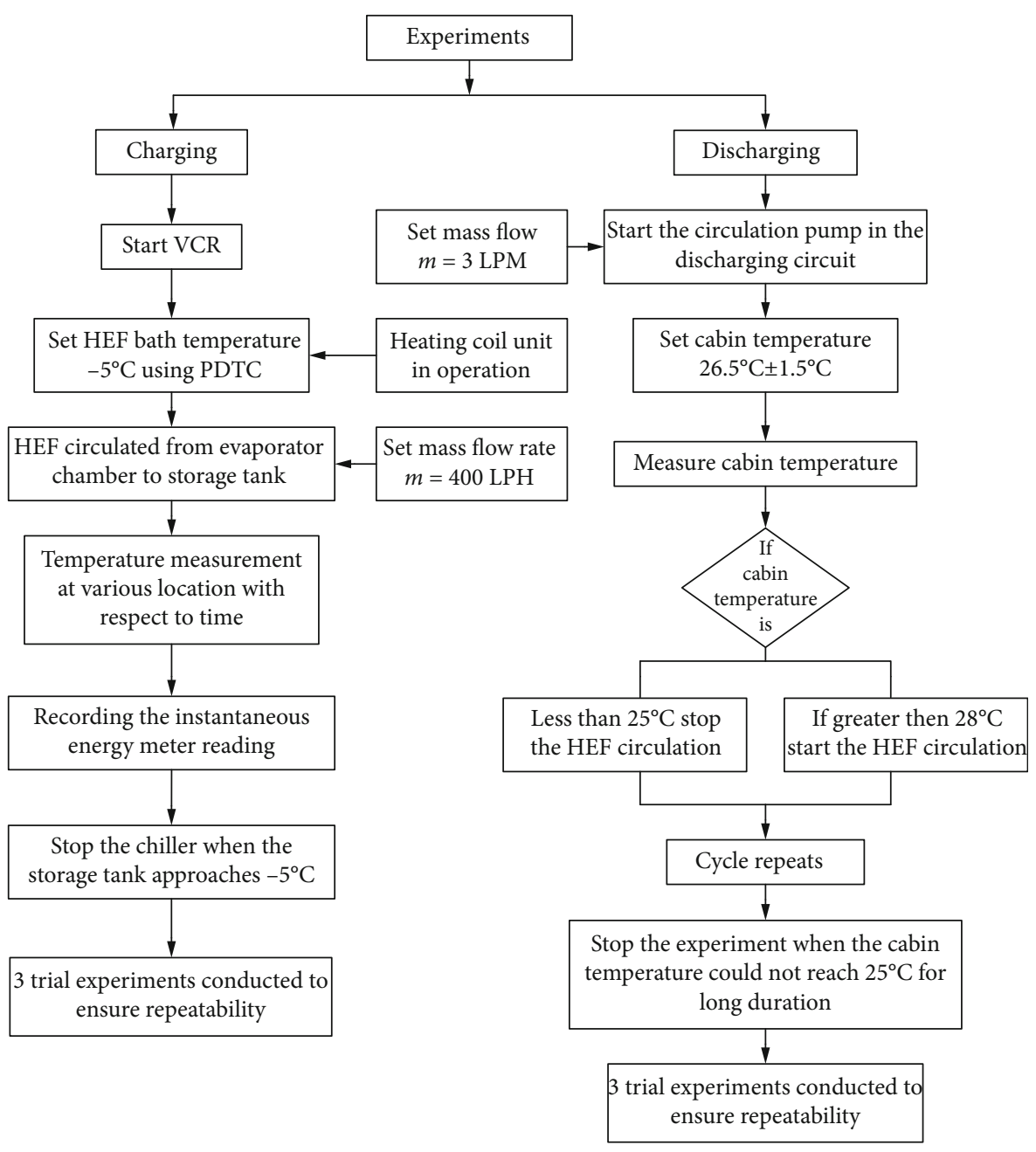

FIgURE 3: Methodology adopted for the experimental investigation.

were noted once in every half an hour. The VCR system was operated continuously, and experiments were continued until the brine in the LTSHS tank approached a temperature of $-5^{\circ} \mathrm{C}$. Figure 3 explains the detailed methodology adopted in the experimental investigation.

Discharging experiments were carried out with brine flow by operating the circulation pump between the LTSHS tank and the cooling coil unit. The brine's uniform mass flow rate was maintained at 3 LPM using the valve arrangement and measured by the flow meter. Average room air temperature at three different locations, one in front of the cooling coil unit and the other two at suitable locations in the room, was considered for the analysis. The brine's inlet and outlet temperature flowing through the cooling coil unit kept in the room was also measured continuously during the experiment. The pump's operation controlled the brine flow from the LTSHS tank to the cooling coil unit for maintaining the room temperature within $26.5 \pm 1.5^{\circ} \mathrm{C}$. The discharging experiments were started when the brine was initially at a temperature of $-5^{\circ} \mathrm{C}$ in the storage tank. The discharging experiment was discontinued when the available brine from the storage tank could not attain the room temperature of nearly $25^{\circ} \mathrm{C}$. Many experiments were conducted to ensure its repeatability. The heat transfer (i.e., instantaneous and cumulative), the heat loss while charging, and the cooling load while discharging were evaluated using the mass flow rate and measured temperatures of the HEF. The technical specification of components involved in the present system is shown in Table 1 .

An estimation of the uncertainties in the measured/derived data was made, and the values are shown in Table 2.

\section{Data Analysis}

The instantaneous heat transfer, cumulative energy stored, and heat removed from the room were evaluated using the measured temperature values, and the equations used for the estimation of these parameters are presented.

The instantaneous heat transfer (the rate at which the thermal energy is stored in the storage tank) during the charging process is estimated using

$$
Q_{\text {ins }}=m C_{p}\left(\text { Tout }-T_{\text {in }}\right), \mathrm{kW} \text {, }
$$

where $m$ is the mass flow rate of the HTF through the storage tank $\left(\mathrm{kg} \mathrm{s}^{-1}\right), C_{p}$ is the specific heat capacity of HTF 
TABLE 1: Technical specifications of system components.

\begin{tabular}{lc}
\hline Components & Rated capacity/range/make \\
\hline VCR system & 1 TR (3.5 kW) \\
Evaporator tank capacity & 11 litres \\
Refrigerant & R 134a \\
\hline HEF circulation pump (chiller unit to LTSHS tank) & 0.25 horsepower (hp) \\
HEF circulation pump (LTSHS tank to cooling unit) & 100 Watts \\
CTES tank capacity & 212 litres \\
\hline Flow meters: & VA-make \\
(i) Charging circuit & $0-1000$ LPH \\
(ii) Discharging circuit & $0-180$ LPH \\
Thermocouple & T-type \\
HEF & HDPE-ethylene \\
\hline
\end{tabular}

TABLE 2: Uncertainty in various measured/derived quantities.

\begin{tabular}{lc}
\hline Measured quantities & Accuracy/error (\%) \\
\hline Temperature & $\pm 0.1^{\circ} \mathrm{C}$ \\
Volume $(100 \mathrm{ml})$ & $\pm 0.015 \mathrm{ml}$ \\
Mass flow rate & $\pm 2.7 \%$ \\
\hline Derived quantities & Error $(\%)$ \\
\hline Instantaneous heat transfer & $\pm 1.85 \%$ \\
\hline
\end{tabular}

$\left(\mathrm{kJ} \mathrm{kg}^{-1} \mathrm{~K}^{-1}\right), T_{\text {in }}$ is the inlet temperature of the HTF in the storage tank at any instant $(\mathrm{K})$, and $T_{\text {out }}$ is the outlet temperature of the HTF in the storage tank at any instant (K).

The cumulative heat transfer $\left(Q_{\text {cum }}\right)$ is estimated by integrating the instantaneous heat transfer $Q_{\text {ins }}$ using

$$
Q_{\text {cum }}=\sum_{k=1}^{n} Q_{\text {ins }}^{k} \bullet \Delta t, \mathrm{~kJ}
$$

where " $n$ " is the number of time steps and $\Delta t$ is the size of each time step (10 seconds considered in the present evaluation).

The heat removed $\left(Q_{R}\right)$ from the room during the discharging process in each cycle of operation is evaluated using

$$
Q_{R}=m C_{p}\left(T_{\text {out ave }}-T_{\text {in,ave }}\right) \times \tau, \mathrm{kW},
$$

where $m$ is the mass flow rate of the HTF through the cooling coil unit $\left(\mathrm{kg} \mathrm{s}^{-1}\right), T_{\text {in, ave }}$ is the average inlet temperature of the HTF to the cooling coil unit in each cycle $(\mathrm{K})$, $T_{\text {out ave }}$ is the average outlet temperature of the HTF from the cooling coil unit in each cycle $(\mathrm{K})$, and $\tau$ is the time taken for the completion of cycle (sec).

\section{Results and Discussion}

The results of the experiments performed during the charging/discharging of the storage tank and cooling of the room by discharging the cool thermal energy are presented and discussed in this section.
4.1. Temperature-Time History of Brine during Charging Process. Figure 4 shows the temperature-time history of the brine at the inlet, outlet, and inside of the storage tank when the brine from the buffer tank set point temperature was maintained at $-5^{\circ} \mathrm{C}$ and the mass flow rate was maintained at $400 \mathrm{LPH}$. It is seen from the figure that the variations in $\mathrm{HEF}$ temperature from the initial state (i.e., at $35^{\circ} \mathrm{C}$ ) to $5^{\circ} \mathrm{C}$ is approximately linear, and the water temperature at the outlet and the water inside the tank coincide. The figure shows that the time taken for the sensible cooling of the brine from $35^{\circ} \mathrm{C}$ to $0^{\circ} \mathrm{C}$ is approximately $550 \mathrm{~min}$ and the time taken for the sensible cooling of the brine from $0^{\circ} \mathrm{C}$ to $-5^{\circ} \mathrm{C}$ is approximately $150 \mathrm{~min}$. It is construed from the figure that the time taken for the same reduction of $\Delta T$ of brine has increased when the VCR system is operated to reduce the brine temperature below $0^{\circ} \mathrm{C}$ compared to above $0^{\circ} \mathrm{C}$. The process ended when the brine reached at $-5^{\circ} \mathrm{C}$, owing to appreciable incremental time required to reduce the temperature further. It is construed from the results that it is efficient to operate the chiller set point temperature around $+5^{\circ} \mathrm{C}$. However, this demand may increase the size of the storage tank, to store the same quantity of cool energy. It should be noted that for every $1^{\circ} \mathrm{C}$ increase in set point temperature, there is an increase of $2.5 \%$ COP (Velraj et al. [5]). Hence, increasing the set point temperature from $-5^{\circ} \mathrm{C}$ to $5^{\circ} \mathrm{C}$ may yield an increased COP of $25 \%$.

4.2. Instantaneous Heat Transfer and Cumulative Energy Storage. Figure 5 shows the instantaneous heat transfer and the cumulative energy stored in the storage tank, which was evaluated continuously from the measured temperature difference between the inlet and outlet brine (i.e., brine entry/exit of the storage tank). The figure shows that the instantaneous heat transfer initially started to decrease from $1.2 \mathrm{~kW}$ and extended for $250 \mathrm{~min}$, and instantaneous heat transfer of $0.8 \pm 0.1 \mathrm{~kW}$ is maintained for $250 \mathrm{~min}$ to 600 min. Further, when operating below $0^{\circ} \mathrm{C}$, an appreciable decrease in instantaneous heat transfer is noticed due to the reduction in the VCR system's performance. The figure also shows that the cumulative energy stored is increasing linearly until the end of charging. During the complete charging, the approximate energy stored was $38,000 \mathrm{~kJ}$. The time taken for 


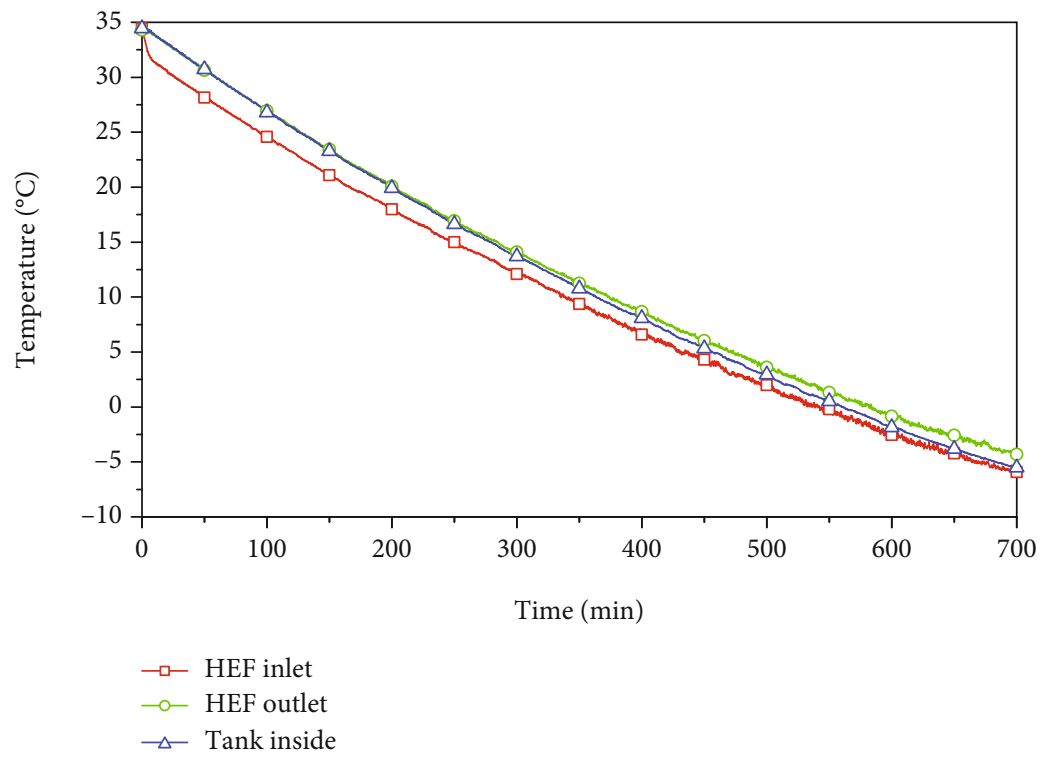

Figure 4: Temperature-time history of brine at inlet, outlet, and inside of the tank for a mass flow rate of $400 \mathrm{LPH}$.

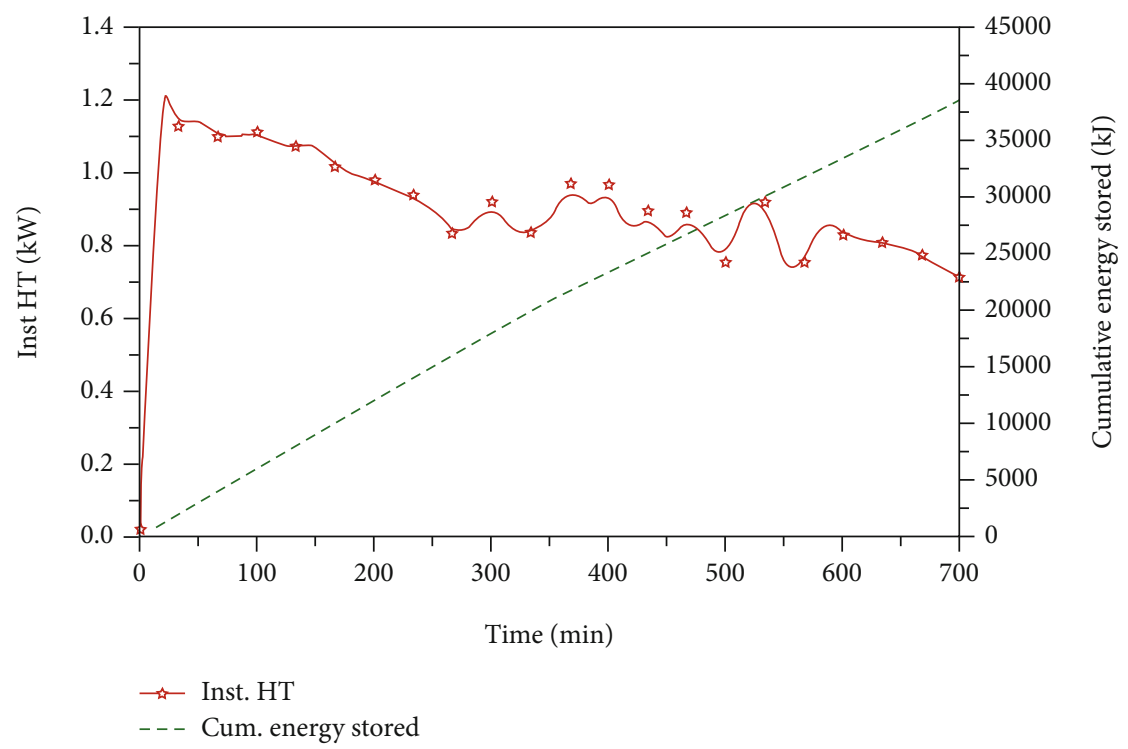

FigURE 5: Instantaneous heat transfer and cumulative energy stored in the storage tank for a mass flow rate of $400 \mathrm{LPH}$.

the entire charging was 700 min. During the chiller's operation, the energy meter was seen consuming one $\mathrm{kW}$-hr as the power consumption for every one-hour operation. It is construed from the above results that nearly $80 \%$ of the cool energy available in the storage tank could be charged at a near-uniform rate.

4.3. Variation of COP of VCR with Brine Temperature Reduction for Every $5^{\circ} \mathrm{C}$ Drop. Figure 6 shows the variation in COP of the VCR system for cooling of 200 litres of brine from its initial temperature of $34.5^{\circ} \mathrm{C}$ to the final temperature of $-5^{\circ} \mathrm{C}$ and the time taken for every reduction in brine temperature of $5^{\circ} \mathrm{C}$. The figure shows that the COP varies with marginal difference from 2.4 to 1.5 for every $5^{\circ} \mathrm{C}$ of brine temperature reduction until reaching the brine temperature to $+5^{\circ} \mathrm{C}$. Further, as brine temperature reduces from $+5^{\circ} \mathrm{C}$ to $-5^{\circ} \mathrm{C}$, the COP of the VCR system reduces appreciably. Hence, it is construed that the VCR system should be operated to bring the brine solution only up to $+5^{\circ} \mathrm{C}$ for better performance and economical way of using the storage tank integrated with the VCR system.

4.4. Discharging Process. The brine temperature at the inlet and outlet of the cooling coil units is an important parameter based on which the heat transfer to the room and thereby the cabin temperature will be maintained. These parameters are studied and reported in this section.

4.4.1. Temperature-Time History of Brine in the Cooling Coil Unit and Cabin Temperature. Figure 7 shows the temperature-time history of the room and the brine inlet/outlet of the cooling coil unit when the set point 


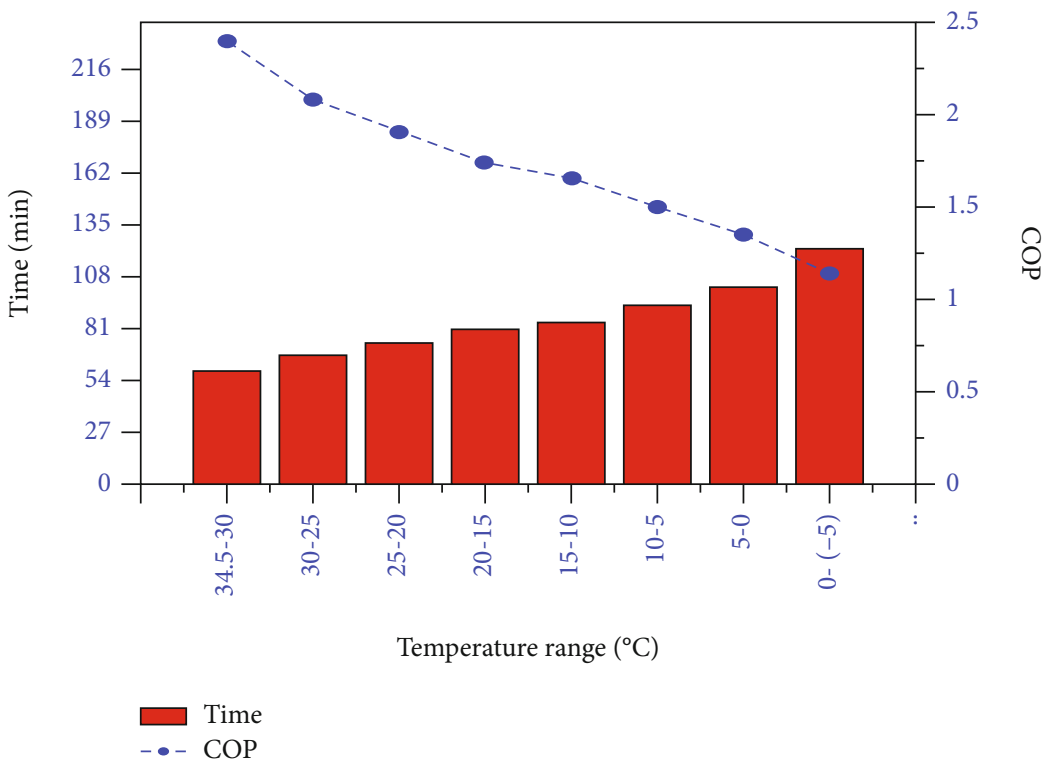

FIgURE 6: Time duration of HEF temperature reduction for every $5^{\circ} \mathrm{C}$ drop and corresponding COP of VCR.

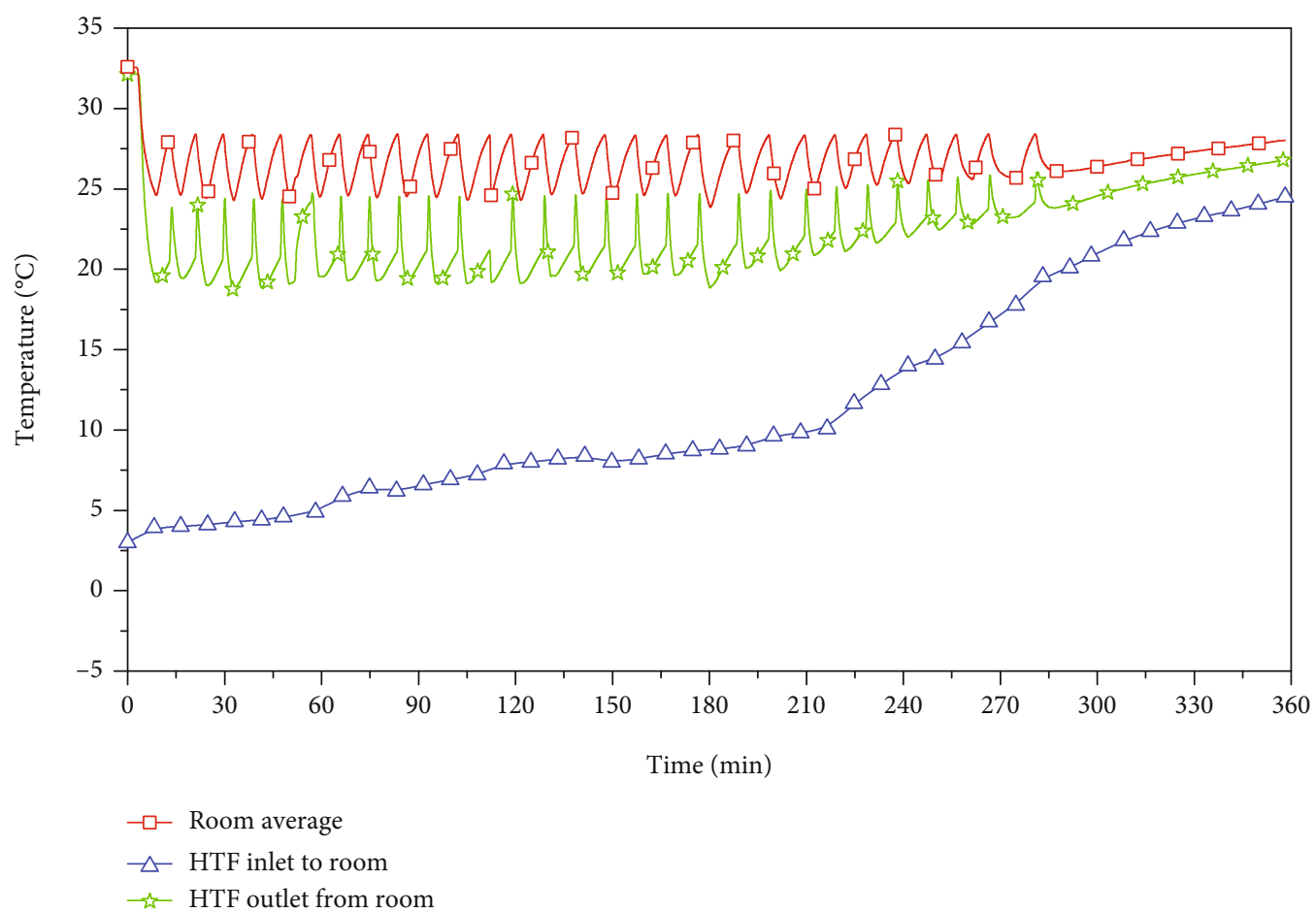

FIgURE 7: Temperature-time history of the room and the brine inlet/outlet of the cooling coil unit.

temperature in the room was maintained between $25^{\circ} \mathrm{C}$ and $28^{\circ} \mathrm{C}$, and the mass flow rate of the brine was maintained at 3 LPM. During each cyclic operation (time taken from $25^{\circ} \mathrm{C}$ to $28^{\circ} \mathrm{C}$ and back to $25^{\circ} \mathrm{C}$ is one cycle), when the brine circulation was stopped, inlet and outlet brine temperatures of the cooling coil unit were increased until the room temperature reached $28^{\circ} \mathrm{C}$. When the circulation was started, the inlet temperature of brine in the room decreased, and the flow was continued till the room temperature reached $25^{\circ} \mathrm{C}$. It is seen from the figure a sharp increase in the room tempera- ture when the brine circulation is stopped and decreases when the brine circulation is started through the cooling coil unit. In addition to that, the idle condition's duration is more than the duration of the circulation of brine in one cycle. It was observed that the room could be maintained at the required comfort condition for a duration of $285 \mathrm{~min}$ with 29 cycles of operation. When the inlet brine temperature of the cooling coil unit reached $20^{\circ} \mathrm{C}$, bringing down the room temperature to $25^{\circ} \mathrm{C}$ could not be achieved and hence the experiment was stopped at that stage and hence it is 


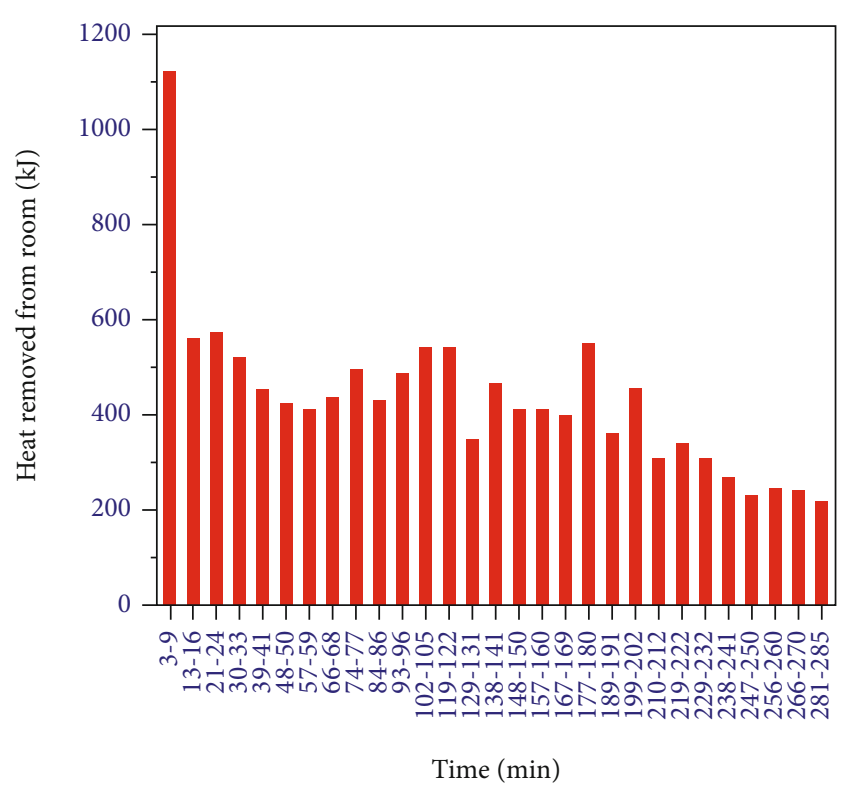

FIGURE 8: Heat removed from the cabin by HEF during each cycle of operation.

construed that further cool energy is not available in the storage tank to produce the required cooling effect in the room.

4.4.2. Heat Removed from the Room. The heat transferred from the room by the brine during each cycle of operation is shown in Figure 8, which indicates that the heat removed from the room is in the range of $300 \mathrm{~kJ}$ to $600 \mathrm{~kJ}$ during all cycles of operation. The variation could be due to the changes in the cooling load required as there was a variation in the heat leak to the room during the experiment. It was observed that the first cycle of operation completes during 3-9 min and the heat removal is more since the temperature is reduced from $32^{\circ} \mathrm{C}$ to $25^{\circ} \mathrm{C}$.

The heat removal required decreased in the last few cycles of operations because of lesser $\Delta T$ between room and brine temperatures. Further, the total heat removed from the room during the entire discharging cycle was evaluated as $12,560.5$ $\mathrm{kJ}$, which was only $60 \%$ of the cool energy initially available in the storage tank. This is due to the higher heat loss from the storage tank and the loss through the piping and other valve joints between the storage tank and room.

\section{Conclusions}

In the present work, experimentations were done to find the heat transfer behavior while charging/discharging process in a cool thermal storage tank of capacity $38,000 \mathrm{~kJ}$. The major conclusions arrived from the charging/discharging experiments are summarized in this section.

(i) During the charging process, when the HEF temperature decreases from $35^{\circ} \mathrm{C}$ to $-5^{\circ} \mathrm{C}$, the time taken to achieve a temperature drop of $5^{\circ} \mathrm{C}$ increases appreciably below $+5^{\circ} \mathrm{C}$

(ii) The COP of the chiller system also reduces appreciably when the HEF temperature decreases below $5^{\circ} \mathrm{C}$ (iii) Hence, it is recommended to operate the storage system with a temperature not less than $+5^{\circ} \mathrm{C}$ to achieve higher efficiency

(iv) When the inlet brine temperature of the cooling coil unit reached $20^{\circ} \mathrm{C}$, in the subsequent cycle, bringing back the room temperature to $25^{\circ} \mathrm{C}$ could not be achieved

(v) The heat removed from the room is in the range of $300 \mathrm{~kJ}$ to $600 \mathrm{~kJ}$ during all the cycles of operation

The cool energy released during the discharging process was only $60 \%$ of energy charged. This is due to the considerable heat loss incurred through various modes which should be avoided. This ensures the requirement of the distance between the storage tank and cooling coil unit to be very close and the storage tank/piping to be insulated very well to prevent heat loss during the storage period and during the passage of flow.

The major scope and the limitations are as follows.

In the near future, when the renewable energy share increases, the demand for cool thermal storage will increase and this kind of LTSHS system is used to smoothen the fluctuations in the solar operated VCR system and to keep the electricity grid smart as large share of electricity is being deployed in building air-conditioning applications. The economic benefits of this cool thermal storage system will be very high if the dynamic tariff is introduced, as in practise in some of the countries in order to keep the grid smart. However, when the capacity of the cooling unit increases, the requirement of the storage tank size also increases appreciably. Hence, in the thickly populated cities, due to space constraints, implementation becomes difficult.

\section{Nomenclature}

CCS: Combined cool storage

AC: $\quad$ Air conditioning

HEF: Heat exchanging fluid

COP: Coefficient of performance

CTES: Cool thermal energy storage

TR: Tonnage refrigeration

LTES: Low-temperature energy storage

VCR: Vapour compression refrigeration

CWES: Chilled water energy storage

LTSHS: Low-temperature sensible heat storage

TES: Thermal energy storage

LPM: Litres per minute

VARS: Vapour absorption refrigeration system

$\mathrm{CO}_{2}$ : Carbon dioxide

PDTC: Potential differential temperature controller

LCC: Life cycle cost

RTD: Resistance temperature detector

LPH: Litres per hour.

\section{Data Availability}

All data used to support the findings of this study are included within the article. 


\section{Conflicts of Interest}

The authors declare that there is no conflict of interest regarding the publication of this article.

\section{References}

[1] X. Cao, X. Dai, and J. Liu, "Building energy-consumption status worldwide and the state-of-the-art technologies for zeroenergy buildings during the past decade," Energy and Buildings, vol. 128, pp. 198-213, 2016.

[2] K. Panchabikesan, K. Vellaisamy, and V. Ramalingam, "Passive cooling potential in buildings under various climatic conditions in India," Renewable and. Sustainable Energy Reviews, vol. 78, pp. 1236-1252, 2017.

[3] M. J. Sebzali, B. Ameer, and H. J. Hussain, "Comparison of energy performance and economics of chilled water thermal storage and conventional air-conditioning systems," Energy and Buildings, vol. 69, pp. 237-250, 2014.

[4] H. Lin, X. H. Li, P. S. Cheng, and B. G. Xu, "Study on chilled energy storage of air-conditioning system with energy saving," Energy and Buildings, vol. 79, pp. 41-46, 2014.

[5] R. Velraj, M. Cheralathanand, and S. Renganarayanan, "Energy management through encapsulated PCM based storage system for large building air conditioning application," International Energy Journal, vol. 7, pp. 253-259, 2006.

[6] M. H. Kim, J. E. Son, J. Heo, D. Kim, and D. W. Lee, "Energy saving potential of an independent dedicated outdoor air system integrated with thermal energy storage for a childcare center," Applied Thermal. Engineering, vol. 152, pp. 377-390, 2019.

[7] C. Yan, W. Shi, X. Li, and Y. Zhao, "Optimal design and application of a compound cold storage system combining seasonal ice storage and chilled water storage," Applied Energy, vol. 171, pp. 1-11, 2016.

[8] S. Boonnasa and P. Namprakai, "The chilled water storage analysis for a university building cooling system," Applied Thermal Engineering, vol. 30, no. 11-12, pp. 1396-1408, 2010.

[9] M. J. Sebzali and P. A. Rubini, "The impact of using chilled water storage systems on the performance of air cooled chillers in Kuwait," Energy and Buildings, vol. 39, no. 8, pp. 975-984, 2007.

[10] X. Song, L. Liu, T. Zhu, S. Chen, and Z. Cao, "Study of economic feasibility of a compound cool thermal storage system combining chilled water storage and ice storage," Applied Thermal Engineering, vol. 133, pp. 613-621, 2018.

[11] H. Lin, X. H. Li, P. S. Cheng, and B. G. Xu, "Thermoeconomic evaluation of air conditioning system with chilled water storage," Energy Conversion Management, vol. 85, pp. 328-332, 2014.

[12] G. P. Henze, B. Biffar, D. Kohn, and M. P. Becker, "Optimal design and operation of a thermal storage system for a chilled water plant serving pharmaceutical buildings," Energy and Buildings, vol. 40, no. 6, pp. 1004-1019, 2008.

[13] S. Rosiek and F. J. Batlles Garrido, "Performance evaluation of solar-assisted air-conditioning system with chilled water storage (CIESOL building)," Energy Conversion Management, vol. 55, pp. 81-92, 2012.

[14] S. Rosiek and F. J. Batlles, "Reducing a solar-assisted airconditioning system's energy consumption by applying realtime occupancy sensors and chilled water storage tanks throughout the summer: A case study," Energy Conversion Management, vol. 76, pp. 1029-1042, 2013.

[15] M. Sadat-Mohammadi, S. Asadi, M. Habibnezhad, and H. Jebelli, "Robust scheduling of multi-chiller system with chilled-water storage under hourly electricity pricing," Energy and Buildings, vol. 218, article 110058, 2020.

[16] G. Alva, Y. Lin, and G. Fang, "An overview of thermal energy storage systems," Energy, vol. 144, pp. 341-378, 2018.

[17] X. She, L. Cong, B. Nie et al., "Energy-efficient and -economic technologies for air conditioning with vapor compression refrigeration: a comprehensive review," Applied Energy, vol. 232, pp. 157-186, 2018.

[18] G. Li, "Sensible heat thermal storage energy and exergy performance evaluations," Renewable and Sustainable Energy Reviews, vol. 53, pp. 897-923, 2016.

[19] G. Li and X. Zheng, "Thermal energy storage system integration forms for a sustainable future," Renewable and. Sustainable Energy Reviews, vol. 62, pp. 736-757, 2016.

[20] R. Narayanasamy, P. Vellaichamy, M. R. Sharma, and V. Ramalingam, "Experimental investigation on packed bed cool storage system for supply-demand management in building air-conditioning system suitable for micro thermal grid," Thermal Science, vol. 25, no. 1 Part A, pp. 95-106, 2021. 